\section{Visitor Responses to an Ethnic Garden Display in a Botanical Garden}

\author{
Melissa Steinhauer ${ }^{1}$, M.A. Brennan ${ }^{2,4}$, Dennis McConnell ${ }^{1}$, \\ Carrie Reinhardt-Adams ${ }^{1}$, and David Sandrock ${ }^{3}$
}

AdDitional InDEX words. African-Americans, diversity, attitude, demographics profiles

Summary. Program developers and administrators in settings such as botanical gardens are increasingly in need of information on the needs and interests of various groups. A need also exists for information on how to broaden interests in garden displays (exhibits including both plants and signs centered on a theme or topic) and increase the diversity of visitors. This article reports on research that explored visitor perceptions of an ethnic garden display highlighting African-American contributions to horticulture. The research also examined overall attitudes toward a botanic garden in Florida where the display was constructed. The results suggested that race did not affect visitors' overall attitudes toward a botanic garden. Younger visitors, those who visit gardens more, and weekend visitors had a more positive attitude toward botanic gardens. Race was, however, related to visitor attitude toward the ethnic display. African-Americans liked the African-American horticulture display more than any other ethnic group. Sociodemographic characteristics, frequency of botanic garden visits, and time of year for visits all shaped visitor attitudes and opinions.

$\mathrm{M}$ any gardens receive a major portion of their annual income from visitors, either in the form of earned income (e.g., admissions fees or gift shop sales) or contributions. It is therefore vital that administrators, designers, and program developers have a clear understanding of the factors shaping visitor attitudes and opinions. This is particularly true as new and more diverse audiences are being catered to and their visitorship promoted. Lowe (1993) reported that, of gardens that receive financial support from the government, one-fifth of garden operating budgets were from earned income, with the largest portion of earned income from admissions and a quarter from contributions. Out of all privately contributed dollars to botanic gardens annually, one-fifth is composed of individual contributions (Arnoult, 1993). If gardens continue

The authors acknowledge the support and assistance of Geraldine Thompson, Myron Floyd, Deborah Johnson-Simon, Robert Bowden, and the staff of Leu Gardens for their help in this project.

${ }^{1}$ Department of Environmental Horticulture, University of Florida, P.O. Box 110670, Gainesville, FL 3261

${ }^{2}$ Department of Family, Youth, and Community Sciences, 3002 McCarty Hall, University of Florida, P.O. Box 110310, Gainesville, FL 32611-0310

${ }^{3}$ Department of Horticulture, Oregon State University, Corvallis, OR 97331.

${ }^{4}$ Corresponding author. E-mail: brennanM@ufl.edu. to rely heavily on individual donations, they must remain cognizant of public interests and wants. Meeting these increasingly diverse interests and needs is further complicated as perceptions of experiences vary. Such perceptions have been found to vary significantly among different groups (Robinson, 1996). In this light, even publicly supported museums must prove their effectiveness through their ability to serve the public if they are to receive continued support (Karp and Lavine, 1993).

Ideally, gardens should appeal to all ethnic groups. However, the majority of visitors to botanic gardens are predominantly European-American (Andorka, 1999). Research has shown that African-Americans visit museums $20 \%$ to $30 \%$ less than the general population (Falk, 1998b). While income and educational attainment play a role in museum appreciation and visitation, race also is shown to play a role (Falk, 1998b). Because botanic gardens are considered museum-like institutions, these statistics can be generalized to botanic gardens as well (Falk, 1998b).

A variety of factors are seen as shaping interests and visitation habits among ethnic groups. Falk, in research focusing on the museum attitudes, visitation, and related factors of African-Americans, identified reasons for nonattendance (Falk, 1995). The leading reasons given for nonattendance were usually lack of interest or lack of time. Equally important, content was frequently mentioned as a reason to visit. Different types of museums (art museums or arboretums) were seen as attracting different types of visitors because of inherent differences in content (Falk, 1993; Falk and Dierking, 1992). Interesting, quality displays are one of the primary reasons individuals visit museums (Falk, 1998a). Sociodemographic characteristics such as gender, race, income, education, and occupation also significantly correlate with museum visitation (Falk, 1998a).

Similarly, Hood (1983) noted that individuals differ psychologically in leisure-time preferences among nonvisitors of museums, occasional visitors of museums (one or two times per year), and frequent visitors (three or more times per year). Frequent visitors value doing something worthwhile, new experiences, and learning opportunities as the most important aspects of their leisure time choices. This contrasts with occasional and nonvisitors, who prefer being comfortable, active participation, and social interaction in their leisure time. Visitors to museums also differ among time of year visited, especially between fall/winter and spring/ summer (Hood, 1988).

This article investigates the extent to which differences in demographics and visitation habits influenced visitors' interest in ethnic garden displays and botanic gardens. This research was guided by the following questions: How do different racial groups view ethnic displays? Do Caucasian visitors find an AfricanAmerican display more or less interesting than African-American visitors? Do demographic variables or garden visitation affect attitude toward botanic gardens?

\section{Materials, methods, and analysis}

Because individuals' responses to a botanic garden display were being studied, the unit of analysis was the individual. As units of analysis, individuals may be characterized in terms of their membership in social groupings, such as racial groups (Babbie, 1998). The population under study 
was adult visitors to Leu Gardens in Orlando, FL. In 2004, Leu Gardens had 121,537 visitors. A cross-sectional design was used because the researchers were not able to collect sufficient data before installation of a specialized display. Cross-sectional studies are appropriate when it is not possible to collect data before and after "treatment," in this case, the display installation (DeVaus, 2001). They are particularly useful when looking at a point in time and exploring the conditions that shape visitor behaviors.

Site selection. Harry P. Leu Gardens in Orlando, FL, was selected as the site for the display and visitor survey. This selection was based on the reasonable proximity to University of Florida, its high visitor rate, and the sociodemographic makeup/ diversity of the region in which the garden was located. Equally important, Leu Gardens is recognized as a major botanical garden. It is widely respected and seen as "a true plantsman's garden” (R. Bowden, personal communication). This location was also appropriate because the garden had made no previous efforts to increase visitor diversity, but had expressed an interest in doing so. Although the percentage of AfricanAmericans in Orange County, FL, was higher than the national percentage [Orange County $=18 \%$, U.S. = $12 \%$ (U.S. Census Bureau, 2004)], the staff at Leu Gardens had observed very low rates of visitation by AfricanAmericans.

Display installation. An African-American horticulture display was installed in the vegetable garden section of Leu Gardens in May 2005. The display included plants introduced to America from Africa by slaves, plants used by African-American scientists, and plants used medicinally by African-Americans in the southern U.S. over the past two centuries. For example, eggplant (Solanum melongena) and okra (Abelmoschus esculentus) were included in the display as examples of plants introduced from Africa (Carney, 2001). Corn (Zea mays) and cowpeas (Vigna unguiculata) are examples of plants that AfricanAmerican scientist George Washington Carver used in experiments (McMurry, 1981). Some plants used medicinally are comfrey (Symphytum officinale) and mullein (Verbascum spp.) (Mitchell, 1999).

The display was laid out like a typical home vegetable garden with rows of vegetables, a path in the center, and a fence enclosing it. A large sign near the entrance gave an overview of the display with brief descriptions of the three main topics and one or two examples of plants in each topic. Smaller signs at the ends of the rows identified plants with their common, scientific, and family names and described their specific significance. For example, if it was a medicinal plant, then the small sign identified the part of the plant used medicinally and for what medical condition. The small signs also included interesting facts, such as the difference between sweetpotatoes (Ipomoea batatas) and yams (Dioscorea spp.). In addition, brochures were distributed at the entrance to the botanic garden that provided more in-depth descriptions and listed sources for additional information. The brochures, instead of focusing on the specific plants, told more of the historical background, such as the lives of the African-American scientists and how the vegetables were introduced. The plants in the display were maintained by the staff at Leu Gardens.

INSTRUMENT DEVELOPMENT. After the display was established and in place for 3 months, self-completion questionnaires were distributed to and collected from adult (age 18 years and older) visitors at the Leu Gardens exit. The questionnaire consisted of 27 items, including Likert-type, control boxes, fill-in-the-blank items, and open-ended questions. Within the questionnaire, a five-item scale measured attitude toward the garden overall, and a seven-item scale measured attitude toward the African-American horticulture display. Interest in vegetable gardening and interest in ethnic displays were also measured using multi-item Likert-type items. Sociodemographic variables were measured using control boxes. Garden visitation was measured with a combination of control boxes and fill-in-theblank items.

The questionnaire was reviewed by an expert panel, which included administrators from the Wells' Built Museum of African-American History in Orlando, FL, an associate professor at University of Florida who conducts research on the topic of race, ethnicity, and leisure, and a researcher who focuses on Florida African-Americans and their support of African-American museums. Shortly after the display was installed, a pilot test of the questionnaire was conducted with 30 participants using the planned distribution methods; 10-30 subjects were considered appropriate for such a pilot test (Babbie, 1998; Isaac and Michael, 1997).

SAMPLING. Availability sampling, which selects subjects on the basis of availability, was used because it was impossible to develop a complete sampling frame (Sullivan, 2001). Specifically, it was not possible to randomly select out of all garden visitors or even out of garden visitors in a given year. Instead, the researchers sampled from all visitors during operating hours (between 10:00 AM and 5:00 PM) on a variety of days and seasons. The research was conducted in both summer and fall because the types of visitors are thought to differ between spring/summer and fall/ winter (Hood, 1988). Research was also conducted on both weekends and weekdays, as weekday visitors were thought to possibly differ demographically from weekend visitors. Participants were sampled on every day of the week for this study. Participants were chosen by asking all visitors leaving the garden during the surveying times to participate. Because there are $\approx 120,000$ visitors to Leu Gardens in a given year, a minimum sample size of 384 was required to represent the visitor population at the 0.05 level of confidence (Krejcie and Morgan, 1970). This goal was exceeded, and a final sample size of 450 was obtained. Leu Gardens had no previous data on their visitors beyond number of visitors, thus the samples could not be further validated or compared with prior data. However, the displays, attendance rates, and other conditions were similar to previous years, suggesting that our sample and population were not substantially different from usual conditions. In addition, $\approx 10 \%$ of individuals approached to participate in the survey refused. There was no noticeable pattern or consistent demographic profile of those refusing.

VARIABles INCLUded IN THE ANALYSIS. Several carefully chosen variables were included in the 
analysis. Dependant variables included overall attitude toward the botanic garden, attitudes toward the African-American horticulture display, and preference for ethnic displays.

Attitude toward Leu Gardens was measured using a Likert-type scale with response options ranging from 1 (strongly disagree) to 5 (strongly agree). Included were the following statements: I would recommend Leu Gardens to my family and friends; my visit to Leu Gardens was boring; I would like to visit Leu Gardens again in the next 6 months; I would like to visit Leu Gardens again in the next year; and I do not want to visit Leu Gardens again. The data were factor-analyzed using several models/rotations (principal-axis factoring and least-squares methods with varimax, quartimax, and direct oblimin rotations). The criteria established in advance of the selection of factor items were: a factor loading of 0.35 or higher; at least a 0.10 difference between the item's loading with its factors and each of the other factors; and interpretability (Kim and Mueller, 1978). In all analyses, only one factor was identified which had an eigenvalue greater than 1.0. Additionally, review of the scree test plots indicated that a one-factor solution was most appropriate. The scale reported high levels of reliability $(\alpha=0.75)$.

Attitudes toward the AfricanAmerican horticulture display were again measured with a Likert-type scale $(1=$ strongly disagree, $5=$ strongly agree). Included in this scale were the following statements: I would recommend the AfricanAmerican display to my family and friends; the African-American horticulture display was very interesting; there should be more displays like the African-American horticulture display in botanic gardens; the AfricanAmerican horticulture display was boring; the African-American horticulture display was the most interesting part of the garden; I would like to visit the African-American horticulture display again in the next year; and I would like to visit the AfricanAmerican horticulture display again in the next 6 months. The same analytical procedures and factor-analysis methods previously conducted were used. The scale reported high levels of reliability ( $\alpha=0.86$ ). Preference for ethnic displays was measured using a single Likert-type item $(\mathrm{l}=$ strongly disagree, 5 = strongly agree). This item stated, "Botanic gardens should have more displays about the garden practices of different ethnic groups."

Independent variables included ethnicity (European or EuropeanAmerican = 1, Black or African-American $=2$, American Indian or Alaskan native $=3$, Asian $=4$, Native Hawaiian or other Pacific Islander $=5$, Hispanic $=$ 6 , Other $=7)$, gender $($ female $=0$, male $=1)$, age $(18-29$ years $=1,30$ 39 years $=2,40-49$ years $=3,50-59$ years $=4,60-69$ years $=5,70-79$ years $=6,80$ years or older $=7$ ), income (under $\$ 9,999=1$, $\$ 10,000-29,999=2, \$ 30,000-$ $49,999=3, \$ 50,000-69,999=6$, $\$ 70,000-89,999=5, \quad \$ 90,000-$ $99,999=6, \$ 100,000-499,999=7$, $\$ 500,000$ and over $=8$ ), education (kindergarten-8th grade $=1$, 9th12th grade $=2$, high school diploma $=$ 3 , two-year degree $=4$, Bachelor degree $=5$, Master degree $=6$, Doctorate degree $=7$ ), previous visitation to Leu Gardens (no $=0$, yes $=1$ ), Leu Gardens visits per year, previous visitation of other botanic gardens $($ no $=$ 0 , yes $=1$ ), other garden visits per year, day of visit (weekend $=1$, weekday $=0$ ), and season of visit (fall $=0$, summer $=1$ ). For attitude toward the African-American horticulture display, preference for vegetable gardening was also included. Preference for vegetable gardening was measured using a single Likert-type item $(1=$ strongly disagree, $5=$ strongly agree) . This item stated, "I enjoy vegetable gardening."

AnaLysis. Relationships between the independent variables and dependent variables were examined using a series of bivariate and multivariate analyses. The multivariate analysis and in particular, the linear regression method gives us a more accurate depiction of how variables realistically interact by considering many independent variables simultaneously instead of their individual relationships to the dependent variable. To better understand ethnicity, dummy variables were used for ethnic classifications in the regression. Because an African-American display was installed, African-Americans were chosen as the reference category for the dummy variables. Similar independent variables (e.g., demographic variables, other variables) were grouped together into separate models and then into one overall model to better observe how the variables interact. Throughout the analysis the minimum significance level was set at $\alpha=0.05$.

\section{Results}

Thirty-eight percent of visitors had been to Leu Gardens before, but $84 \%$ had visited other botanic gardens. Visitors were mostly female (61.6\%), European-American (77.8\%), had higher levels of education $(55.7 \%)$, and were middle-aged (age 40-49 years) or younger (60.3\%). The sample was divided between the two seasons, with $54 \%$ of the sample visiting in summer and $46 \%$ in fall. A larger part of the sample population visited on weekends $(70.8 \%)$ than on weekdays $(28.9 \%)$. Visitation times (season or day of week) for the most part did not differ significantly across the various demographics. The few exceptions that were noted include females $\left(\chi^{2}=\right.$ $8.644, P<0.005)$ and older people $\left(\chi^{2}=38.167, P<0.001\right)$ being more likely to visit on weekdays. Those with high levels of education were slightly more likely to visit during the fall $\left(\chi^{2}=15.072, P<0.01\right)$.

Overall atTitude toward the GARDEN. The scale measuring attitude toward Leu Gardens showed no relationship between demographic variables and attitude toward the botanic garden at the bivariate level. Although demographic variables were not statistically significant, several other variables were. Included were those related to timing of the visit and previous garden visits. Attitude toward the garden was significantly related to season of the year, with summer visitors having less-positive attitudes $\left(\chi^{2}=11.321, P<0.05\right)$. Additionally, individuals who visited on weekends usually liked the garden more than those who visited on weekdays $($ weekend $=1, r=0.150, P<$ $0.001)$.

Attitude toward the garden was positively related to previous visitation. Those who had previously visited Leu Gardens had a more positive attitude toward the garden $(r=$ $0.240, P<0.001)$, and those who 
visited more frequently liked the garden more than those who visited less frequently $(r=0.107, P<0.05)$. There was also a significant positive relationship between attitude and visits per year to other botanic gardens $(\gamma=0.242, P<0.001)$.

Relationships between the independent variables and attitude toward Leu Gardens overall were further explored in a three-stage regression model (Table 1). Model 1 examined the demographic variables alone, Model 2 included the visitation habits variables, and Model 3 included all independent variables together. This final model was reduced by systematically deleting nonsignificant variables to achieve the most parsimonious model. Significant variables in the reduced model included age (negatively related), previous visits to Leu Gardens (positive), visited others before (positive), and day of week (weekend visitors responding more positively). These significant variables accounted for $9 \%$ of the variation in the model $\left(R^{2}=0.09\right)$.

AtTitude TOWARD THE African-American HORTICUlture DISPLAY. The scale measuring attitudes toward the African-American display showed significant differences in response with respect to a demographic variable. Higher-income visitors had a more negative attitude toward the display $(r=-0.125, P<$ $0.05)$. Attitude did not differ significantly for any other demographic variable.

Looking beyond the demographic characteristics, both previous visitors to Leu Gardens and frequent visitors to other gardens had a more positive attitude toward the display $(r=0.120, P<0.05$ and $r=0.143$, $P<0.05$, respectively). Visitors who enjoy vegetable gardening also had a more positive attitude toward the display $(r=0.258, P<0.001)$. Thus, preference for vegetable gardening was included specifically in this model because the display was a vegetable garden; a visitor who typically did not like ethnic displays may have enjoyed the display because it contained vegetables and vice versa.

As with the previous attitudinal scale, relationships between the independent variables and attitude toward the African-American display were compared in three different regression models (Table 2). The reduced model overall included income (negative relationship), education, ethnic classifications (attitudes

of each ethnic group compared with attitudes of African-Americans), Leu Gardens visits per year, other garden visits per year, and vegetable

Table 1. Regression analysis of the effects of demographic and visitation habits on overall attitudes toward botanic gardens (standardized regression coefficients are shown).

\begin{tabular}{|c|c|c|c|c|}
\hline & $\begin{array}{c}\text { Model 1: } \\
\text { Demographics }\end{array}$ & $\begin{array}{c}\text { Model 2: } \\
\text { Visitation } \\
\text { habits }\end{array}$ & $\begin{array}{c}\text { Model 3: } \\
\text { Overall } \\
\end{array}$ & $\begin{array}{c}\text { Reduced } \\
\text { overall }\end{array}$ \\
\hline \multicolumn{5}{|l|}{ Demographic variables } \\
\hline Gender $($ male $=1)$ & 0.009 & & -0.002 & \\
\hline Age & $-0.184^{* * *}$ & & $-0.177 * * *$ & $-0.155^{* *}$ \\
\hline Income & 0.065 & & 0.054 & \\
\hline Education & 0.028 & & -0.025 & \\
\hline European-American & 0.118 & & 0.076 & \\
\hline Asian & 0.008 & & 0.022 & \\
\hline Hispanic or Latino & 0.055 & & 0.044 & \\
\hline Other race & -0.022 & & -0.048 & \\
\hline \multicolumn{5}{|l|}{ Visitation habits } \\
\hline Visited Leu Gardens before & & $0.205^{* * *}$ & $0.186 * * *$ & $0.204 * * *$ \\
\hline Leu Gardens visits per year & & 0.090 & 0.095 & \\
\hline Visited other gardens before & & 0.040 & 0.098 & $0.108^{*}$ \\
\hline Other garden visits per year & & -0.032 & -0.033 & \\
\hline Season of year $($ summer $=1)$ & & 0.024 & 0.025 & \\
\hline Day of week (weekend = 1) & & $0.144^{* *}$ & $0.121^{*}$ & $0.122^{*}$ \\
\hline$R^{2}$ adjusted & 0.019 & 0.070 & 0.081 & 0.091 \\
\hline$F$ & 1.929 & 6.664 & 3.477 & 10.868 \\
\hline Cases (no.) & 386 & 447 & 379 & 389 \\
\hline
\end{tabular}

$*, * * * * *$ Significant at $P \leq 0.05,0.01$, or 0.001 , respectively.

Table 2. Regression analysis of the effects of demographic and visitation habits on attitudes toward African-American horticulture displays at botanic gardens (standardized regression coefficients are shown).

\begin{tabular}{|c|c|c|c|c|}
\hline & $\begin{array}{c}\text { Model 1: } \\
\text { Demographics }\end{array}$ & $\begin{array}{c}\text { Model 2: } \\
\text { Visitation } \\
\text { habits }\end{array}$ & $\begin{array}{c}\text { Model 3: } \\
\text { Overall }\end{array}$ & $\begin{array}{c}\text { Reduced } \\
\text { overall } \\
\end{array}$ \\
\hline \multicolumn{5}{|l|}{ Demographic variables } \\
\hline Gender $($ male $=1)$ & -0.045 & & -0.010 & \\
\hline Age & -0.016 & & -0.072 & \\
\hline Income & $-0.156^{*}$ & & -0.145 & $-0.149 *$ \\
\hline Education & $0.162 *$ & & 0.161 & $0.136^{*}$ \\
\hline European-American & -0.230 & & $-0.288^{*}$ & $-0.197^{*}$ \\
\hline Asian & -0.046 & & -0.122 & \\
\hline Hispanic or Latino & -0.194 & & $-0.248^{*}$ & $-0.174^{*}$ \\
\hline Other race & $-0.165^{\star}$ & & $-0.216^{* *}$ & $-0.183^{* *}$ \\
\hline \multicolumn{5}{|l|}{ Visitation habits } \\
\hline Visited Leu Gardens before & & -0.027 & -0.015 & \\
\hline Leu Gardens visits per year & & 0.083 & $0.179 *$ & $0.178 * *$ \\
\hline Visited other gardens before & & -0.119 & -0.120 & \\
\hline Other garden visits per year & & $0.153^{*}$ & $0.157^{*}$ & $0.138^{*}$ \\
\hline Season of year $($ summer $=1)$ & & -0.026 & -0.038 & \\
\hline Day of week (weekend = 1) & & -0.021 & -0.068 & \\
\hline Like vegetable gardening & & $0.257 * * *$ & $0.263^{* * *}$ & $0.251 * * *$ \\
\hline$R^{2}$ adjusted & 0.030 & 0.083 & 0.155 & 0.158 \\
\hline$F$ & 2.007 & 4.719 & 4.089 & 6.267 \\
\hline Cases (no.) & 249 & 280 & 237 & 243 \\
\hline
\end{tabular}

$*, * *, * * *$ Significant at $P \leq 0.05,0.01$, or 0.001 , respectively. 
gardening. These significant variables accounted for $16 \%$ of the variation in the model $\left(R^{2}=0.16\right)$.

INTEREST IN ETHNIC DISPLAYS. The data revealed that several demographic characteristics were significantly related to interest in ethnic displays. Minority individuals, or those of ethnicities other than EuropeanAmerican, were more likely to be interested in ethnic displays than European-Americans $(r=0.111, P<$ $0.05)$. More highly educated visitors also had more interest in ethnic displays than less-educated visitors $(r=$ $0.110, P<0.05$ ).

In addition to demographics, visitation habits were also important to interest in ethnic displays. Ethnic display interest was less for summer visitors than fall visitors ( summer $=1$, $r=-0.128, P<0.01)$. Interest also had a significant relationship with both Leu Gardens visits per year $(F=$ $3.008, P<0.05)$ and other garden visits per year $(F=6.059, P<0.01)$.

The relationships between the independent variables and attitude toward ethnic displays were compared in three different regression models (Table 3 ). In the final reduced model, significant variables included education (positive relationship), European-American ethnicity (European-Americans less interested than
African-Americans), and visitation season (summer visitors being less interested). These significant variables accounted for $5 \%$ of the variation in the model $\left(R^{2}=0.05\right)$.

\section{Discussion}

This research represents the attitudes and opinions of 450 visitors to a major botanical garden during Summer and Fall 2005. The demographics of the sample for this study were predominantly female, younger, European/European-American, and in the upper education and income categories. Respondents do not reflect the overall community but are thought to be consistent with the overall profile of Leu Gardens visitors. Even so, comparing visitor and community demographics will help gardens better understand the issues they face. If gardens wish for more community support, an understanding of which demographic groups visit, and why, will help garden staff to better serve those groups. Alternately, observing which groups visit more will, in part, help gardens to understand what they do well.

Surprisingly, the sample was younger overall. This was possibly influenced by the garden being located in proximity to four colleges.

Table 3. Regression analysis of the effects of demographic and visitation habits on attitudes toward ethnic displays at botanic gardens (standardized regression coefficients are shown).

\begin{tabular}{|c|c|c|c|c|}
\hline & $\begin{array}{c}\text { Model 1: } \\
\text { Demographics }\end{array}$ & $\begin{array}{c}\text { Model 2: } \\
\text { Visitation } \\
\text { habits }\end{array}$ & $\begin{array}{c}\text { Model 3: } \\
\text { Overall } \\
\end{array}$ & $\begin{array}{c}\text { Reduced } \\
\text { overall } \\
\end{array}$ \\
\hline \multicolumn{5}{|l|}{ Demographic variables } \\
\hline Gender $($ male $=1)$ & -0.024 & & 0.034 & \\
\hline Age & 0.007 & & -0.052 & \\
\hline Income & -0.085 & & -0.090 & \\
\hline Education & $0.160 * *$ & & $0.130^{*}$ & $0.108^{*}$ \\
\hline European-American & $-0.250 * *$ & & $-0.246^{* *}$ & $-0.175^{* * *}$ \\
\hline Asian & 0.012 & & -0.010 & \\
\hline Hispanic or Latino & -0.088 & & -0.092 & \\
\hline Other race & -0.066 & & -0.056 & \\
\hline \multicolumn{5}{|l|}{ Visitation habits } \\
\hline Visited Leu Gardens before & & -0.056 & -0.059 & \\
\hline Leu Gardens visits per year & & 0.220 & 0.187 & \\
\hline Visited other gardens before & & 0.044 & 0.069 & \\
\hline Other garden visits per year & & -0.201 & -0.163 & \\
\hline Season of year $($ summer $=1)$ & & $-0.110^{*}$ & $-0.108^{*}$ & $-0.131 * *$ \\
\hline Day of week (weekend = 1) & & -0.043 & -0.064 & \\
\hline$R^{2}$ adjusted & 0.048 & 0.015 & 0.052 & 0.052 \\
\hline$F$ & 3.386 & 2.063 & 2.518 & 8.031 \\
\hline Cases (no.) & 369 & 422 & 372 & 383 \\
\hline
\end{tabular}

$\star *, *, * *$ Significant at $P \leq 0.05,0.01$, or 0.001 , respectively.
This may also reflect the content of botanic gardens; science museums typically attract younger visitors than do art or history museums (Hood, 1983). Some older visitors may also be deterred by the perception of heavy walking at botanic gardens. Gardens could substantially benefit from involving its younger population as volunteers and donors. Special events or giving clubs for younger donors can help achieve this; for $\mathrm{ex}^{-}$ ample, Brooklyn Botanic Garden (Brooklyn, NY) has a "New Leaders Circle" with an annual event for young professionals (Brooklyn Botanic Garden, 2004). One younger respondent suggested that the garden should "get local colleges/universities involved."

Differences in racial composition were also noticed between the overall community and the visitor sample. As previously established in the literature, visitors to botanic gardens are most often European-American (Andorka, 1999). This was consistent in our sample. While Orange County, FL, is only $57.5 \%$ European-American (U.S. Census Bureau, 2004), the visitor sample was $>77 \%$ EuropeanAmerican. The percentage of Asians was actually higher in the sample (4.1\%) than in Orange County as a whole (3.4\%). African-Americans (5.5\% of sample) and Hispanics $(8.8 \%$ of sample) were drastically under-represented when compared with Orange County demographics (18.2\% of population and $18.8 \%$ of population, respectively). This highlights the need for more research and program development designed to attract and serve all segments of the population, especially minority and ethnic groups. Example of applied efforts could include specialized outreach efforts through low-income schools, community groups in disadvantaged areas, and religious organizations. As part of these outreach efforts, formal invitation and special culturally significant displays could be used.

In addition to the sociodemographic differences seen, a variety of conditions were found to shape the attitudes and opinions of respondents. The overall attitude toward the botanic garden was influenced by several factors. According to the model, those who have the most positive attitude toward Leu Gardens are younger, weekend visitors who 
have visited a botanic garden before (Leu Gardens or otherwise). Younger visitors had more positive attitudes toward the garden than did older visitors.

Also, weekend visitors viewed the garden more favorably than did weekday visitors. When age and day of week were compared, weekend visitors were significantly younger than weekday visitors $(r=-0.229$, $P<0.001)$. No previous research has mentioned differences between weekend and weekday visitors to botanic gardens or museums. The finding that younger visitors were more likely to frequent the garden on weekends provides a valuable opportunity. Included would be specialized events designed to specifically appeal to a younger audience. The inclusion of a younger market and support base would likely prove to be a valuable resource in long-term efforts to sustain the garden.

Previous visits to Leu Gardens and other gardens were also important in shaping attitudes. This was consistent with previous research (Hood, 1983). Both present options for applied program and policy development. Because previous garden visitation is also important to attitude, school field trips and young-adult events may be ways to increase interest in botanic gardens later in life. One participant suggested in response to the open-ended questions that gardens should "introduce school programs, field trips, etc., targeted at children. Start working on the next generation of garden lovers." Similarly, efforts to include young adults and their social groups would help to familiarize them with botanic gardens and enhance their likelihood of future visits.

The research showed a variety of characteristics that shaped perceptions and attitudes toward the African-American display. All ethnic groups except Asians were observed to have a less positive attitude toward the African-American display than the African-Americans. This suggests that display content geared to a specific ethnic group will indeed be interesting to that ethnic group. One participant enthusiastically commented about the display, "If we have an (African-American) section, I want a Polish-American, German-American, and Asian-American section." This research corresponds with previous research that suggests African-Americans, especially, visit museums because of interesting display content (Falk, 1995). Following this finding, botanic gardens should create ethnic displays focusing on a particular ethnic group that is prevalent in their community to attract more of that group. For example, Matthaei Botanical Gardens (Ann Arbor, MI) observed that $30 \%$ to $50 \%$ of visitors to their "Out of Africa" exhibit were African-American (Michener and Klatt, 1999). Similarly, rotating displays could be developed to draw in a wider variety of visitors and also contribute to greater cultural understanding.

These findings also have implications for increasing future attendance, when compounded by the significant finding that previous visits to Leu Gardens or other gardens were positively related to return visits. Visitors also had a more positive attitude toward the display if they visited Leu Gardens and other botanic gardens more frequently. Previous research has observed that more-frequent garden visitors value learning as an important part of their free-time activities (Hood, 1983). Perhaps more-frequent visitors liked the African-American display better because it was an opportunity to learn something new. Other significant variables were interest in vegetable gardens, education, and income. Interest in vegetable gardening held the strongest relationship with attitude toward the African-American display because it was a vegetable garden display. Future displays should integrate more landscape plants, in addition to or instead of vegetable plants, to appeal to a wider audience. The significant relationship of educational attainment suggests that visitors with higher levels of education were more interested in the African-American display. Program planners could build on this by promoting the educational and learning potentials associated with specific uniquely designed displays that highlight particular cultures. Similarly, by partnering with educational institutions, displays and related garden events could be presented to a wider market. Lastly, the negative relationship of income was surprising. This suggests that visitors with lower incomes saw the display more favorably than did those of higher income levels. This may be tied to sociodemographic disparities among visitors of different races. Program planners can use this finding by developing and promoting displays that may be of interest to select groups who may be socially or economically disadvantaged.

The results for interest in ethnic displays in general were consistent with what was expected and similar in attitude toward the African-American horticulture display. The evidence suggests that people with higher education prefer ethnic displays. Several participants, especially highly educated individuals, commented that they would have liked additional information in the AfricanAmerican display, such as "more information about the historic implications of African-American horticulture" and "more information about gardening practices." Based on these findings, gardens can better satisfy their more-educated visitors more closely considering every aspect of the topic of a display and providing very detailed information regarding the subjects of their displays. Looking at the results further, EuropeanAmericans overall had less interest in ethnic displays than African-Americans. Based on observation, this is likely because many visitors are more interested in learning about things that are of particular relevance to them or their culture. Gardens should acknowledge this reality as they plan ethnic displays but also balance comfort with new ideas and exposure to new beliefs, cultures, and backgrounds.

Unexpectedly, season was a significant variable. This may in part be due to different patterns of visiting. Summer visitors may have been the result of special trips, conference tours, and other unique conditions. Alternatively, fall visitors may be more regular visitors who are familiar with displays and the uniqueness of the garden content.

Increasing visits, attracting new types of visitors, and expanding diversity of content is of increasing interest to program developers, administrators, and planners. This research suggests that ethnicity may play an important role in visitor behavior, attitudes, and visitation practices. This study also highlights a variety of 
factors that shape opinions toward gardens, ethnic displays in general, and ethnic displays designed to highlight the contributions of a specific population (e.g., African-Americans). Finally, this research also suggests that ethnic displays may be a viable method for attracting and serving minority populations. This would certainly be useful in fostering greater diversity of content and visitors at our gardens.

\section{Literature cited}

Andorka, C. 1999. A five-step plan for diversifying your audience. Public Garden 14(4):17-20.

Arnoult, L. 1993. 124 billion reasons why you should do fundraising. Public Garden 8(1):28-30.

Babbie, E. 1998. The practice of social research. 8th ed. Wadsworth Publishing, Belmont, CA.

Brooklyn Botanic Garden. 2004. Annual report 2003. 27 Jan. 2005. <http:// www.bbg.org/abo/annualreport/ 2003/2003_annualreport.pdf>.

Carney, J.A. 2001. Black rice: the African origins of rice cultivation in the Americas. Harvard University Press, Cambridge, MA.

DeVaus, D. 2001. Research design in social research. Sage Publications, Thousand Oaks, CA.
Falk, J.H. 1993. Leisure decisions affecting African-American use of museums. Amer. Assn. Museums, Washington, D.C.

Falk, J.H. 1995. Factors influencing African-American leisure time utilization of museums. J. Leisure Res. 27(1):41-61.

Falk, J.H. 1998a. A framework for diversifying museum audiences. Museum News 77(5):36-39, 61.

Falk, J.H. 1998b. Visitors-who does, who doesn't, and why (why people go to museums). Museum News 77(2):38-43.

Falk, J.H. and L.D. Dierking. 1992. The museum experience. Whalesback Books, Washington, DC.

Hood, M.G. 1983. Staying away: why people choose not to visit museums. Museum News 61(4):50-57.

Hood, M.G. 1988. A comprehensive approach to audience development. Public Garden 3(3):16-18.

Isaac, S. and W. Michael. 1997. Handbook in research and evaluation. 3rd ed. Edits, San Diego.

Karp, I. and S.D. Lavine. 1993. Communities and museums: partners in crisis. Museum News 72(3):44-45, 69.

Kim, J. and C. Mueller. 1978. Factor analysis: statistical methods and practical issues. Sage Publications, Beverly Hills, CA.
Krejcie, R.V. and D.W. Morgan. 1970. Determining sample size for research activities. Educ. Psychol. Meas. 30:607-610.

Lowe, C.B. 1993. Funding strategies: where does your garden get its money? Public Garden 8(1):14-15, 36-37.

McMurry, L.O. 1981. George Washington Carver: scientist and symbol. Oxford University Press, New York.

Michener, D.C. and B. Klatt. 1999. Peoples, plants, and cultures at the University of Michigan Matthaei Botanical Gardens. Public Garden 14(2):27-30.

Mitchell, F. 1999. Hoodoo medicine: Gullah herbal remedies. Summerhouse Press, Columbia, SC.

Robinson, F. 1996. The people-plant connection: while people are dependant on plants, botanic gardens are dependant on people. Public Garden 11(2):18-20, 43.

Sullivan, T.J. 2001. Methods of social research. Harcourt, Orlando, FL.

U.S. Census Bureau. 2004. Orange County, FL-selected characteristics of the total and native population. 25 Mar. 2007. <http://factfinder.census.gov/ servlet $/$ STTable?_bm $=y \&-$ context $=$ st $\&$ qr_name=ACS_2004_EST_G00_S0601\&ds_name $=$ ACS_2004_EST_G00_\&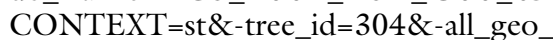 types $=$ N\&-geo_id $=05000$ US $12095 \&$ format $=\&$-_lang $=\mathrm{en}>$. 